\title{
The Effect of Financial Performance and Balanced Funds on Capital Expenditure of Local Government in District/City in Indonesia
}

\author{
Kornelis Kopong Bolen \\ Student in Accounting Master, Faculty of Economics and Business \\ Sebelas Maret University, Surakarta, Indonesia \\ E-mail: nek.kopong@gmail.com
}

Payamta

Faculty of Economics and Business

Sebelas Maret University, Surakarta, Indonesia

E-mail: payamtaakuntan@gmail.com

Received: Oct. 7, 2019 Accepted: Oct. 24, 2019 Online published: Nov. 15, 2019

doi:10.5296/jpag.v9i4.15583～URL: https://doi.org/10.5296/jpag.v9i4.15583

\begin{abstract}
Many regional governments in district/city still allocate their capital expenditures below $30 \%$. It is not in line with expectations as mandated in Regulation of the Minister of Home Affairs on Guidelines for Preparation of Regional Income and Expenditure Budget (APBD). The purpose of this study is to examine the effect of financial performance and balance funds on the allocation of capital expenditures for district /city governments in Indonesia. The sample used in this study were 473 district/city governments consisting of 382 district governments and 91 city governments. Meanwhile, the type of data used was secondary data. The analysis in the study was based on reports on the realization of the 2013 to 2017 budget audited by The Supreme Audit Agency of The Republic of Indonesia (BPK).

The results of multiple regression analysis show first, Regional Financial Independence and General Allocation Funds have a negative but significant effect on Capital Expenditures. Second, Regional Financial Effectiveness, Revenue Sharing Funds, and Special Allocation Funds have a positive and significant effect on Capital Expenditures. Third, Regional Financial Efficiency does not significantly affect Capital Expenditures.
\end{abstract}


Keywords: financial performance, balance funds, capital expenditures, local governments

\section{Introduction}

Since the reformation era which conducted a reformed bureaucracy and local finance in 1998, there has been a drastic shift in the Indonesian government from a centralized to a decentralized paradigm. The difference of these paradigms is the delegation of authority. Decentralization system better addresses the shifting trajectory of globalization because the government, private sectors and community are obliged to synergize for developing a prime local area to participate in the national, regional and global competitions (Waris, 2012). Furthermore, decentralization bestows a broader authority to the provincial or district government for running an effective and efficient administration (Suwanda and Santosa 2014).

Also, decentralization system is stipulated by the Law No. 22, 1999 and Law No 25, 1999 on autonomy and fiscal decentralization. However, the laws have been amended multiple times before taken over by Law no 9, 2015 on the Second Amendment of Law No 23, 2014 on Local Government, and Law No 33, 2004 on Balance Funds between Central Government and Local Government. As the two Laws made official, local governments are bestowed a more extensive autonomy along with different rights and obligations including the obligation to manage and maintain administration affairs and to serve the public.

In addressing the essence and challenges that accompany the objective of the Law, Halim (2012) stated that regional autonomy is the best way to boost regional development as it allows independent administration for effective and efficient development. Therefore, regional autonomy could encourage the local government to conduct more developments that eventually foster public welfare and justice through the improved service, empowerment, and enabled community (Suprayitno, 2015; Aryawati and Sudana, 2018). Regional autonomy requires local government to exercise independence in organising and developing the area by harnessing resources, i.e. human resources (men), natural resources (materials), financial resources (money), and utilizing the correct equipment (machines) and methods according to the necessity and priority of each region.

One of the resources highlighted in the decentralization system is the management of financial resources. Financial resource is an area of local government obligation elaborated in the Local Government Budget (APBD) about the government programs and activities for financing regional development. APBD consists of two programs for the local government in one budget period - revenue and expenses and expenditure in case of budget deficit presented in numbers (Saragih, 2003; Halim, 2007). Also, APBD is defined as an annual budget plan that has been discussed and approved by the local government and the Regional Legislative Council in PP No 71, 2010, and ratified by the regional law in PP No 58, 2005. APBD has to be implemented in a timely manner so that the planned programs are executed within the budget year (Verawaty, Jaya, and Megawati, 2016). Accordingly, APBD is a policy instrument that accommodates several public interests in form of programs and activities to improve public service and social welfare in regional area. 
The financial statements of APBD consist of seven reports, but this research would focus on the Report of Budget Realisation (LRA). In the structure of LRA report, local expenditure consists of operational, capital and unexpected expenditure. Operational expenditure aims to help expedite the implementation of government activity, and it directly impacts the social welfare. Capital expenditure is dedicated to building infrastructure for the community, and the unexpected expenditure is for unusual activities not expected to reoccur such as disaster mitigation, social disaster and other unanticipated expense (PP No. 71, 2010).

This research would highlight the capital expenditure of local government in district/city. One of the general policies of national development in the National Medium-Term Development Plan (RPJMN) 2015-2019 stated that the capital expenditure would accelerate infrastructure building for growth and equity. Also, infrastructure building is directed at strengthening national connectivity to achieve a balanced development; therefore, it implements the agenda of national development to develop Indonesia from the peripheral regions by strengthening regional and rural areas, and to achieve an economic autonomy and generate the strategic economic sectors in domestic level (Nawa Cita item three and seven). To support RPJMN, the local government is required to sync the correlated policies that include planning, regulating, budgeting, agencies and officials, and regional development in the General Budget Policy (KUA) and the Priority of Temporary Budget Ceilings (PPAS) that have been agreed with DPRD through the APBD stipulation.

Mardiasmo (2009) reported that capital expenditure for development would eventually affect the improved social living standard/welfare and public service, and elevate the dignity of the autonomous regions. Accordingly, capital expenditure budget should be relevant with the necessity and the priority of regional development particularly public facility, such as general service and economic activities. Therefore, the Local Government Budgeting Team (TAPD) as the policy maker should restructure APBD allocated for operational expenditure/routine expense that were deemed less productive because of lacking direct impact to social welfare. It was supported by Saragih (2003) that expenditure budget should be allocated for the long-term and productive expenses that actually benefits the society. Furthermore, the Ministerial Decree of Home Affairs on the guideline of Local Government Budget emphasized that the local government prioritize capital expenditure for development and infrastructure building related to improving public service (minimum 30\% of the total APBD). However, LRA report 2013-2017 mentioned that many local governments in district and city level allocated under $30 \%$ or below budget expectation.

Table 1. The trend of Capital Expenditure 2013-2017

\begin{tabular}{|c|c|c|c|c|c|c|c|c|c|c|}
\hline \multirow[b]{2}{*}{$\begin{array}{c}\text { Capital } \\
\text { Expenditure }\end{array}$} & \multicolumn{2}{|c|}{2013} & \multicolumn{2}{|c|}{2014} & \multicolumn{2}{|c|}{2015} & \multicolumn{2}{|l|}{2016} & \multicolumn{2}{|c|}{2017} \\
\hline & $\begin{array}{l}\text { Number of } \\
\text { Local } \\
\text { Government }\end{array}$ & $\%$ & $\begin{array}{l}\text { Number of } \\
\text { Local } \\
\text { Government }\end{array}$ & $\%$ & $\begin{array}{l}\text { Number of } \\
\text { Local } \\
\text { Government }\end{array}$ & $\%$ & $\begin{array}{l}\text { Number of } \\
\text { Local } \\
\text { Government }\end{array}$ & $\%$ & $\begin{array}{l}\text { Number of } \\
\text { Local } \\
\text { Government }\end{array}$ & $\%$ \\
\hline $0 \%-10 \%$ & 5 & 1,06 & 2 & 0,42 & 4 & 0,85 & 0 & - & 2 & 0,42 \\
\hline$>10 \%-20 \%$ & 175 & 37,00 & 162 & 34,25 & 120 & 25,37 & 82 & 17,34 & 101 & 21,35 \\
\hline$>20 \%-30 \%$ & 173 & 36,58 & 190 & 40,17 & 195 & 41,23 & 224 & 47,36 & 264 & 55,81 \\
\hline$>30 \%$ & 120 & 25,37 & 119 & 25,16 & 154 & 32,56 & 167 & 35,31 & 106 & 22,41 \\
\hline Total & 473 & 100,00 & 473 & 100,00 & 473 & 100,00 & 473 & 100,00 & 473 & 100,00 \\
\hline
\end{tabular}


Table 1 shows a fluctuated trend of local governments (district/city) in allocating capital expenditure from 2013 to 2017. The year 2016/2017 saw a drastic decline in the $>30 \%$ capital expenditure, from 167 to 106 out of 473 local governments. Regarding the trend, what were the contributing factors to the fluctuated capital expenditure budget?

The correlating and contributing factors to capital expenditure include financial performance of local government (regional financial autonomy, financial effectiveness and efficiency) and balanced funds transfer from the central government, i.e. Revenue Sharing Funds (DBH), General Funds Allocation (DAU), Special Funds Allocation (DAK), and others.

Nugroho and Dahuri (2012) stated that financial independence of the local government is translated into the ability to create and utilize funding sources for development in realizing social welfare. The financial independence of local government is measured by comparing the Local-Owned Source Revenue (PAD) with transfer revenue from the local government, provincial government and loans. PAD is the retribution of local administrative regions according to regional regulation on local tax and retribution (Haris, 2007). The higher the PAD of a region, the less dependent to external stakeholder to finance the capital expenditure. Therefore, the local government must be able to manage local wealth resources to finance local development and social welfare.

Financial resources for the local government should be managed efficiently and effectively. Mardiasmo (2004) reported a correlation between efficiency and productivity, and between effectivity and target policy achievement. An efficient government has less expenses than the income. Accordingly, the local government has implemented regional expenditure according to the budget plan. Furthermore, an efficient local government would exercise an effective capital expenditure by achieving the stipulated target revenue. The higher the achieved target revenue, the higher the capital expenditure.

Another problem is a significant fiscal imbalance between high-PAD and low-PAD local governments to develop the regions. To address this issue, the central government stipulated Balance Funds in the Law No 33, 2004 that the central government would transfer balance funds including Revenue Sharing Funds (DBH), General Allocation Funds (DAU) and Special Allocation Funds (DAK) so that the local government could implement its authority. The objective of balance funds is to finance regional needs, and to allow the local government to determine and fund special activities according to the national program (equitable principle).

Previous studies on financial performance by Ardhini and Handayani (2011) and Nurhidayati and Yaya (2013) suggest that the financial performance of local government has a negative but significant effect on capital expenditure proportion. Furthermore, regarding an effective and efficient financial performance on capital expenditure of local government, Martini and Dwirandra (2015) stated that financial effectivity did not significantly affect the allocation of capital expenditure. Also, Ardhini and Handayani (2011) and Nurhidayati and Yaya (2013) reported a significant effect of financial effectivity. Studies by Ardhini and Handayani (2011), Nurhidayati and Yaya (2013), and Martini and Dwirandra (2015) suggest that financial efficiency did not affect the capital expenditure of local government. 
A study on the effect of balance funds (DBH, DAU, and DAK) on capital expenditure by Subowo and Wati (2010) and Sofia and Syamsurizal (2010) reported that balance funds are positively correlated with capital expenditure. Some findings reported a negative effect of DAU on capital expenditure (Wandira, 2013; Nurhidayati and Yaya, 2013; Pramesti, Taufik, and Ratnawati, 2015), but some found otherwise (Tuasikal, 2008; Situngkir, 2009; Nuarisa 2013; and Solikin, 2016). Handayani and Nuraina (2012), and Pramesti et al. (2015) reported that DAK did not affect capital expenditure, but Situngkir and Manurung (2009), Nuarisa (2013), and Nurhidayati and Yaya (2013) reported a significant impact.

Based on the disobedient phenomena of the local government (district/city) in Indonesia on the percentage of capital expenditure from the total budget (minimum 30\%) and the past findings on different variable test result, it is important to conduct a further study because the focus of Nawa Cita is to improve infrastructure building as part of capital expenditure. Accordingly, this research is aimed to investigate the impact of financial performance and balance funds on the capital expenditure of local government (district/city) in Indonesia.

\section{Literature Review and Hypothesis}

\subsection{Fiscal Decentralization Theory}

Decentralization according to the Law No 33, article 1 section 8 is the act of delegating authority to the local government to run administration in the Republic of Indonesia. The authority delegation includes administrative, political, and fiscal/financial affairs (Haryanto and Astuti 2009; Cho 2018). A decentralized administration is bestowing administrative authority except decision-making. Decentralized politic means the central government bestows full political authority to the local government, while decentralized fiscal/financial allows full authority to the local government to manage regional monies without any intervention from the central government.

Theory of fiscal decentralization suggests that the entire potentials and resources in the regional are the responsibility of the local governments, and the local policy is the tool to run the programs according to the vision - to focus on the regional necessity (Aryawati and Sudana, 2018). Fiscal decentralization proposes that the local government harness financial resources (self-owned or loans) to conduct social welfare development. The minimum requirement for fiscal decentralization is an adequate authority from the local government to mobilising revenue, and a sound accountability to managing expenditure (Purbadharmaja, Maryunani, Ananda, and Santoso, 2018). Although the local government holds the authority, the central government provides aids and supervision. This definition shows a functional relationship between central and local governments in financial matter (Purbadharmaja et al. 2018). Faguet (2004) and Purbadharmaja et al., (2018) stated that decentralization is crucial for an efficient and effective public service, as well as improving accountability, autonomy, sensibility and public satisfaction (Cho, 2018).

An efficient and effective fiscal decentralization is achievable when the local government could optimally harness financial resources such as PAD or balance funds (DBH, DAU or DAK) for infrastructure building for the society. The obligation to increase PAD is expected 
to improve the financial performance of local government that eventually realises social welfare through infrastructure building (Muryawan and Sukarsa, 2016).

\subsection{The Effect of Local Financial Autonomy (KKD) on Capital Expenditure (CE)}

The Law No. 32, 2004 stipulated that financial autonomy means the government ability to finance administrative programs, development and public service, and to hold accountable the internal finance regarding decentralization principle. Autonomy reflects the local government's level of dependency on external funding source - support from the central government, provincial government and loans. Halim (2007) stated that the higher the financial autonomy ratio, the lower the dependency on external funding source. Based on the financial statements of local governments (district/city) in Indonesia, particularly LRA Report 2013-2017, there had been an annual increase of transfer funding revenue from the central government, provincial government and loans; however, the increasing PAD was not significant. It indicates a high dependency on external funding source.

Ardhini and Handayani (2011) and Nurhidayati and Yaya (2013) reported that local dependency significantly affects local budget proportion for public service. Accordingly, this study proposes a hypothesis as follows:

$\mathrm{H}_{1}$ : Regional financial independence negatively affects capital expenditure.

\subsection{The Effect of Local Financial Effectiveness (LFE) on Capital Expenditure (CE)}

The demand for better public services has required the local government (district/city) in Indonesia to rigorously generate local revenue by increasing PAD as the prominent source for funding the expenditure. A high PAD would enable the local government to undertake regional development without having to wait for central government aid. Also, a high PAD is the characteristic of an autonomous region. Accordingly, an effective governance is able to maintain a higher revenue than the expenses. (Nurhidayati and Yaya, 2013). Martini and Dwirandra (2015) reported that the ratio of local financial effectiveness did not significantly affect the allocation of capital expenditure; however, local financial effectiveness had a positive and significant effect on capital expenditure (Ardhini and Handayani, 2011; Nurhidayati and Yaya, 2013). Based on the statements, this study proposes the second hypothesis:

$\mathrm{H}_{2}$ : Local financial effectiveness has a positive and significant effect on capital expenditure.

\subsection{The Effect of Local Financial Efficiency (LFE) on Capital Eexpenditure (CE)}

Efficiency is related to the expenses to gain revenue and the actual revenue obtained - the higher the actual revenue, the more capital expenditure is allocated for infrastructure building. An efficient local government has a less expenditure than the total revenue. Ardhini and Handayani (2011), Nurhidayati and Yaya (2013), and Martini and Dwirandra (2015) stated that the local financial efficiency had a negative but significant effect on the proportion of capital expenditure. The proposed hypothesis is as follows: 
$\mathrm{H}_{3}$ : Local financial Efficiency negatively affects capital expenditure.

\subsection{The Effect of Revenue Sharing Funds (DBH) on Capital Expenditure (CE)}

In implementing decentralization, addressing imbalance fiscal and supporting regional development, the central government allocates $\mathrm{DBH}$ at certain percentage to the local government (district/city) in Indonesia. DBH is a financial source for local government expenditure. The local government receiving high $\mathrm{DBH}$ should exercise optimum expenditure for a balance development, i.e. improving general public service and economy. Subowo and Wati (2010) reported that balanced funds including DBH is positively correlated with capital expenditure. Similarly, Sofia and Syamsurizal (2010) stated that partial and simultaneous DBH is related to capital expenditure. Accordingly, a hypothesis is proposed below:

$\mathrm{H}_{4}$ : Revenue sharing funds positively affects capital expenditure.

\subsection{The Effect of General Allocation Fund (DAU) on Capital Expenditure (CE)}

The objective of DAU is to balance financial across regions and to secure the minimum standard service. The central government allocates DAU annually for the local government (district/city) for a balance development. DAU is an unconditional grant; therefore, it is important for the local government to allocate the funding based on the regional priority infrastructure building to support better public services. LRA data showed an increasing DAU transfer to the local government (district/city) every year. Consequently, PAD budget plan is not optimal but tend to be higher, expecting a bigger DAU.

Tuasikal (2008), Situngkir (2009), and Nuarisa (2013) reported that DAU positively affects capital expenditure, but Solikin (2016) found that DAU positively affects local expenditure, and Pramesti et al., (2015) stated that DAU did not affect the allocation of capital expenditure. Similarly, Wandira (2013) and Nurhidayati and Yaya (2013) showed that DAU had a negative but significant effect on capital expenditure allocation. The conflicting previous findings suggest that DAU is highly dependent on each local government policy whether for development or operational activity such as staff expenditure. The proposed hypothesis based on the elaboration is as follows:

$\mathrm{H}_{5}$ : General allocation fund negatively affects capital expenditure.

\subsection{The Effect of Special Allocation Funds (DAK) on Capital Expenditure (CE)}

The objective of DAK is for equitable development across regions, particularly for special programs within the local government affairs. Due to its special commission, DAK is dedicated for tangible and intangible capital expenditure for improving public facility.

Pramesti et al., (2015) reported that DAK did not affect capital expenditure allocation. Furthermore, Handayani and Nuraina (2012) stated that partial DAK did not affect local expenditure allocation. However, other studies found that DAK significantly affected capital expenditure (Situngkir and Manurung, 2009; Nuarisa, 2013; Nurhidayati and Yaya, 2013). Therefore, the proposed hypothesis of DAK on Capital Expenditure is as follows: 
$\mathrm{H}_{6}$ : Special allocation funds positively affects capital expenditure.

\section{Research Method}

\subsection{Population and Sample}

The population of this study is derived from the Financial Statements of Local Government (LKPD) of district/city in Indonesia from 2013 to 2017 that has been audited by Audit Board of the Republic of Indonesia (BPK RI), except the local government in the Capital city, DKI Jakarta. The exclusion is because the local governments in DKI Jakarta is not autonomous where the Local Government Budget (APBD) is included in the list financial list of provincial administration. The total population is 508 LKPD that include 415 district LKPD and 93 city LKPD.

A purposive sampling method was applied under some considerations and criteria. The sample criteria for this study were (1) LKPD of (district/city) government that had been audited and listed in BPK RI database 2013-2017; (2) the local government with LKPD listed in the researcher's database; (3) all variables had a complete data set; and (4) the existing and unchanged local governments from 2013 to 2017. The sampling criteria collected 473 LKPD of local governments in Indonesia -382 district LKPD and 91 city LKPD, totalling 2365 observation in five years.

\subsection{Data source and Types}

This study used secondary data - quantitative data that included Statement of Budget Realisation (LRA) as in total revenue, PAD, DBH, DAU, DAK, Provincial Government Aid, Total Loans, Total Expenditure, and Capital expenditure derived from the database of Audit Board of the Republic of Indonesia (BPK RI) based on audit report from 2013 to 2017. Secondary data were used because of the validity guaranteed by other stakeholder which proven reliable for the research.

\subsection{Data Collection}

Data can be collected from different methods including observation, survey, and analysis on secondary data (Nuryaman and Veronika, 2015). Data collection methods for this study were as follows:

a) Analysing secondary data by recording and processing the collected data

b) Conducting literary study by collecting relevant information to the topic or research objectives from documentations, books, literature and other written sources.

\subsection{Measurement and Definition of Operational Variable}

\subsubsection{Dependent Variables}

The dependent variable in this study is capital expenditure. In the Statement of Budget Realisation (LRA) structure, capital expenditure is expenses for capital investment to provide funding for long-term investment that includes land; equipment and machines; buildings and property; road; irrigation and network and other fixed assets. The ratio of capital expenditure 
is below:

$$
\text { Ratio of Capital expenditure }=\frac{\text { Capital Expenditure }}{\text { Total Expenditure }} \times 100 \%
$$

\subsubsection{Independent Variable}

a. Local Financial Autonomy

Local financial autonomy shows the ability of local government to harness the resources to finance administrative activity, development and public service. Local financial autonomy illustrates the extent of local government dependency on external funding source - the higher the ratio, the lower financial dependency on central government, provincial government or loans, and vice versa. The formula of local financial autonomy ratio according to Halim (2007) is as follows:

\section{Autonomy ratio}

PAD

$=\frac{\text { Financial aid from central and provincial governments and loans }}{x} 100 \%$

The ratio criteria of local financial autonomy ratio

\begin{tabular}{cccl}
\hline No & Financial Capacity & $\begin{array}{c}\text { Autonomy } \\
(\boldsymbol{\%})\end{array}$ & Correlation \\
\hline 1 & Very Low & $0-25$ & Isntructive \\
2 & Low & $25-50$ & Consultative \\
3 & Moderate & $50-75$ & Participative \\
4 & High & $75-100$ & Delegative \\
\hline
\end{tabular}

Sources: Halim (2004:189)

b. Local financial effectiveness

Local financial effectiveness is the ratio of local government capacity in realising target PAD (Ardhini and Handayani 2011) based on the actual potentials in the region as stipulated in the Local Government budget (APBD). Financial performance of the local government is effective when the realised PAD is exceeding the target. Therefore, the higher the ratio, the more effective the performance is. The ratio of local financial effectiveness is formulated as follows:

$$
\text { Effectiveness ratio }=\frac{\text { PAD realisation }}{\text { PAD target }} \times 100 \%
$$

The effective criteria of financial performance of local government 


\begin{tabular}{ccc}
\hline No & $\begin{array}{c}\text { Financial Performance } \\
\text { Percentage }\end{array}$ & Criteria \\
\hline 1 & $>100 \%$ & Very Effective \\
2 & $100 \%$ & Effective \\
3 & $90 \%-99 \%$ & Moderately Effective \\
4 & $75 \%-89 \%$ & Less Effective \\
5 & $<75 \%$ & Not Effective \\
\hline
\end{tabular}

Sources: Mahmudi (2010:143)

c. Local Financial Efficiency

Local financial efficiency is the ratio of total cost to the actual revenue, or input to output. The less the efficiency ratio, the higher government performance, or vice versa (Pradiatmi, 2015; Nurhidayati and Yaya, 2013). Efficiency ratio is formulated as follows:

$$
\text { Efficiency ratio }=\frac{\text { Actual cost }}{\text { Actual revenue }} \times 100 \%
$$

The efficiency criteria of local government financial performance

\begin{tabular}{ccc}
\hline No & $\begin{array}{c}\text { Financial Performance } \\
\text { Percentage }\end{array}$ & Criteria \\
\hline 1 & $<10 \%$ & Very Efficient \\
2 & $10 \%-20 \%$ & Efficient \\
3 & $21 \%-30 \%$ & Moderately Efficient \\
4 & $31 \%-40 \%$ & Less Efficient \\
5 & $>40 \%$ & Not Efficient \\
\hline
\end{tabular}

Sources: Mahmudi (2010:143)

d. Revenue Sharing Funds (DBH)

$\mathrm{DBH}$ is a fund allocated for the regional chiefs based on certain percentage to finance regional necessities for Decentralization. DBH ratio in this study is formulated as follows:

$$
\text { DBH ratio }=\frac{\text { Revenue Sharing Funds }}{\text { Total Revenue }} \times 100 \%
$$

e. General Allocation Fund (DAU)

DAU is a fund allocated for the regional chiefs to finance general necessities for an equitable financial capacity across regions (Ardhini and Handayani, 2011). DAU ratio in this research is formulated as follows:

$$
\text { DAU ratio }=\frac{\text { General Allocation Funds }}{\text { Total Revenue }} \times 100 \%
$$


f. Special Allocation Fund (DAK)

Special allocation fund is a fund allocated for some regional chiefs to support special programs such as building infrastructure for general service and economic activities. DAK ratio in this study is as follows:

$$
\text { DAK ratio }=\frac{\text { Special Allocation Funds }}{\text { Total Revenue }} \times 100 \%
$$

\subsection{Analysis Method}

The data were subject to multiple linear regression analysis with $5 \%$ significance rate $(\alpha=0,05)$ or 0,95 confidence rate as follows:

$\mathrm{Y}_{1}=\alpha+\beta_{1} \mathrm{X}_{1}+\beta_{2} \mathrm{X}_{2}+\beta_{3} \mathrm{X}_{3}+\beta_{4} \mathrm{X}_{4}+\beta_{5} \mathrm{X}_{5}+\beta_{6} \mathrm{X}_{6}+\mathrm{e}$

Note:

$\mathrm{Y}_{1}=$ Capital Expenditure $(\mathrm{CE})$

$\mathrm{X}_{1}=$ Local Financial Autonomy $(\mathrm{KKD})$

$\mathrm{X}_{2}=$ Local Financial Effectiveness (EFKT)

$\mathrm{X}_{3}=$ Local Financial Efficiency (LFE)

$\mathrm{X}_{4}=$ Revenue Sharing Funds $(\mathrm{DBH})$

$\mathrm{X}_{5}=$ General allocation fund (DAU)

$\mathrm{X}_{6}=$ Special allocation fund (DAK)

$\alpha=$ constant

$\beta=$ Slope or coefficient regression or intercept for each $X$ variables.

$\mathrm{e}=$ error

Panel data regression determines whether the model is fit for testing hypothesis in this research. The evaluation used software Eviews 9 and the analysis took some steps including descriptive statistics, coefficient determination $\left(\mathrm{R}^{2}\right)$, simultaneous significant test $(\mathrm{F}$ test) and individual parameter significance test $(\mathrm{t}$ test).

\section{Result and Discussion}

\subsection{Descriptive Statistics Analysis}

Table 2. Descriptive Statistics

\begin{tabular}{ccrrrr}
\hline Variable & $\begin{array}{c}\text { Number of } \\
\text { Observation }\end{array}$ & Mean & Maximum & Minimun & $\begin{array}{c}\text { Std. } \\
\text { Deviasi }\end{array}$ \\
\hline CE & 2365 & 25,55 & 77,51 & 4,95 & 8,07 \\
KKD & 2365 & 14,09 & 545,31 & 0,25 & 24,83 \\
EFKT & 2365 & 103,41 & 662,70 & 4,60 & 31,76 \\
LFE & 2365 & 93,40 & 172,60 & 56,30 & 8,31 \\
DBH & 2365 & 7,68 & 78,53 & 0,74 & 11,17 \\
DAU & 2365 & 53,86 & 79,89 & 0,00 & 12,57 \\
DAK & 2365 & 10,73 & 34,98 & 0,00 & 6,30 \\
\hline
\end{tabular}


Source: data processed, 2019

The elaboration of descriptive statistics in this study is presented in Table 2. The observed variables were Capital Expenditure (CE) as the dependent variable - Local Financial Autonomy (KKD), Local Financial Effectiveness (EFKT), Local Financial Efficiency (LFE), Revenue Sharing Funds (DBH), General Allocation Fund (DAU), and Special Allocation Fund (DAK).

a. Dependent variable or the average $\mathrm{CE}$ was $25,55 \%$ indicating that menunjukkan bahwa the local government (district/city) in this sample had not implemented the Decree of Ministry of Home Affairs on the Guideline of Local Government Budget (APBD) that the capital expenditure must be minimum $30 \%$ of total local expenditure. The maximum CE ratio was $77,51 \%$ in South Tangerang city in 2014 , and the least was $4,95 \%$ in Rembang district in 2015 with 8,07\% standard deviation.

b. The independent variables are as follows:

First, the average 14,09\% KKD ratio shows that the local government (district/city) in Indonesia is not independent to manage local finance. In fact, the financial capacity is very low $(0-25 \%)$ so development budget is obtained from external financial aid. The functional relationship between the central and local governments is instructive - central government dominates regional administration because the local government is deemed incapable of running regional autonomy (Halim 2004). The minimum KKD ratio was $0,25 \%$ in Deiyai district in 2017 . However, maximum ratio of some governments shows an independent financial management such as Badung district in 2017 (545,31\%). Second, the average EFKT ratio was $103,41 \%$ indicating a very effective local government financial performance (district/city) because it accomplishes $>100 \%$ financial performance; the higher the ratio, the more effective the financial performance (Mahmudi 2010). The maximum EFKT ratio was $662,70 \%$ in Central Mamberamo district in 2014. Some local governments with ineffective financial performance is reflected from the minimum EFKT ratio (4,60\%) in Biak Numfor district in 2016.

Third, the average LFE ratio was $93,40 \%$ indicating an inefficient financial performance because it does not satisfy the criteria from very efficient $(<10 \%)$, efficient $(10 \%-20 \%)$ to moderately efficient $(21 \%-30 \%)$. In fact, the smaller the ratio, the more efficient the local government's financial performance (Mahmudi 2010). The maximum LFE ratio is 172,60 in Bulungan district in 2015, and the minimum is 56,30\% in Pidie Jaya district in 2017. Fourth, the maximum DBH ratio in 2014 is found in Kutai Kartanegara district (78,53\%), and the minimum ratio is $0,74 \%$ in Timor Tengah Selatan in 2017. Fifth, the maximum DAU ratio was 79,89\% in Kepulauan Aru district in 2014, and the minimum ratio was $0,00 \%$ in Kutai Kartanegara district in 2015.

Finally, the maximum DAK ratio was 34,98\% in Indramayu district in 2013, and the maximum ratio is $0,00 \%$ in Medan city (2015), Dumai city (2013 and 2014), Tanjungpinang city (2014 and 2015), Murung Raya district (2013), Tabalong district 
(2013), Kutai Kartanegara district (2015), Bontang city (2013 and 2014), Tana Tidung district (2014) and Tarakan (2013).

Table 3. The result of regression analysis with dependent variable of Capital Expenditure $(\mathrm{N}=2365)$

\begin{tabular}{lrrl}
\hline \multicolumn{1}{c}{ Variable } & Coefficient & t-Statistic & Prob. \\
\hline KKD & $-0,0720$ & $-4,2146$ & 0,0000 \\
EFKT & 0,0130 & 3,8556 & 0,0001 \\
LFE & 0,2439 & 18,7495 & 0,0000 \\
DBH & 0,1989 & 7,4696 & 0,0000 \\
DAU & $-0,4004$ & $-19,3611$ & 0,0000 \\
DAK & 0,1897 & 8,2087 & 0,0000 \\
C & 20,4452 & 12,8397 & 0,0000 \\
\hline \hline R-squared & 0,8155 & & \\
Adjusted R-squared & 0,7687 & & \\
F-statistic & 17,4369 & & \\
Prob(F-statistic) & 0,0000 & & \\
\hline
\end{tabular}

Source: data processed, 2019

\subsection{Coefficient Determination Test $\left(R^{2}\right)$}

Table 3 shows that the adjusted $R$-squared or coefficient determination is 0,7687 , indicating that $76,87 \%$ dependent variable or Capital expenditure (CE) can be elaborated from six independent variables - Local Financial Autonomy (KKD), Local Financial Effectiveness (EFKT), Local Financial Efficiency (LFE), Revenue Sharing Funds (DBH), General Allocation Fund (DAU) and Special Allocation Fund (DAK). The rest 23,13\% is affected by other variables that were not observed in this study.

\subsection{Simultaneous Significance Test (F test)}

F test was used to observe the simultaneous effect of independent variable on dependent variable. Table 3 shows that the probability value of $F$ test was 0,0000 or significantly smaller than 0,05; therefore, all independent variables including Local financial autonomy (KKD), Local financial effectiveness (EFKT), Local financial Efficiency (LFE), Revenue sharing funds (DAU), General allocation fund (DAU) and Special allocation fund (DAK) simultaneously affect the dependent variable or the Capital Expenditure (CE).

\subsection{Individual Parameter Significance Test (t-test)}

Six independent variables in the regression model have a significant probability at 0,05 . The t-test value interprets whether the independent variable partially affects dependent variables. Table 3 shows regression equation as follows:

$$
\mathrm{CE}=20.445 * \mathrm{C}-0.0720 * \mathrm{KKD}+0.0130 * \mathrm{EFKT}+0.2439 * \mathrm{LFE}+0.1989 * \mathrm{DBH}-
$$


$0.4004 * \mathrm{DAU}+0.1897 * \mathrm{DAK}+\mathrm{e}$

The regression equation shows that independent variables of Local Financial Effectiveness (EFKT), Local Financial Efficiency (LFE), Revenue Sharing Funds (DBH), and Special Allocation Fund (DAK) positively affects capital expenditure. While independent variables of Local Financial Autonomy (KKD) and General Allocation Fund (DAU) negatively affects capital expenditure.

\subsection{Result of Hypothesis Testing}

Table 3 presents the result of hypothesis testing of the independent variables to dependent variable. The ratio of Local Financial Autonomy ratio (KKD) to capital expenditure (CE) results in $-0,0720$ coefficient value and the probability value is $0,0000<\alpha(0,05)$. It indicates that there is a significant effect but nonlinear with the capital expenditure. Accordingly, the first hypothesis that local financial autonomy negatively affects capital expenditure is accepted. The hypothesis testing shows that the local government (district/city) was still highly dependent on financial aid from the central government, provincial government and loans in allocating capital expenditure (building infrastructure for general public service and economic activities); therefore, capital expenditure is assumed to require high expenses. On the other hand, local-owned revenue (PAD) which translates into local financial autonomy is different across regions, and PAD is allocated beyond capital expenditure. This finding is in line with Ardhini and Handayani (2011) and Nurhidayati and Yaya (2013) that local financial autonomy negatively affects local budget proportion for public service.

Hypothesis testing on the ratio of local financial effectiveness (EFKT) to capital expenditure (CE) resulted in $0,0001<\alpha$ probability value $(0,05)$, indicating a significant effect on capital expenditure. Furthermore, coefficient value 0,0130 shows that EFKT ratio had a positive and significant effect on capital expenditure. Accordingly, the second hypothesis that the local financial effectiveness has a positive and significant effect on capital expenditure is accepted. This hypothesis testing shows that the local government (district/city) has very effectively allocated a bigger portion of PAD for capital expenditure to build the infrastructure of public service and economic activities. It was in accordance with Ardhini and Handayani (2011) and Nurhidayati and Yaya (2013) that local financial effectiveness had a positive and significant effect on local financial budget allocated for public service.

The hypothesis testing that the Local Financial Efficiency (LFE) ratio to capital expenditure (CE) had a $0,0000<\alpha$ probability value $(0,05)$ with 0,2439 coefficient value; therefore, LFE ratio did not significantly affect capital expenditure. According to Mahmudi (2010) LFE coefficient value 0,2439 shows a moderate efficiency - the higher efficiency ratio, the more inefficient local financial performance. Despite the positive coefficient trajectory, the relationship between the two variables was not significant. Therefore, the third hypothesis that local financial Efficiency negatively affects capital expenditure is accepted. Hypothesis testing proved that the local government (district/city) paid higher cost to obtain PAD as a revenue, while the allocated funds for capital expenditure saw a declining trend every year. This finding supported Nurhidayati and Yaya (2013) that local financial Efficiency did not 
significantly affect capital expenditure proportion. Also, Ardhini and Handayani (2011) and Martini and Dwirandra (2015) reported that local financial Efficiency had a negative but significant effect on capital expenditure proportion.

Hypothesis testing on the ratio of revenue sharing funds $(\mathrm{DBH})$ to capital expenditure (CE) had a $0,0000<\alpha$ probability value $(0,05)$ with 0,1989 coefficient regression value; therefore, DBH ratio had a positive and significant effect on capital expenditure. Accordingly, the fourth hypothesis that DBH positively affects capital expenditure is accepted. This hypothesis testing shows that the local government (district/city) with a higher DBH would allocate higher proportion for capital expenditure. This finding supports Subowo and Wati (2010) that balanced funds (including DBH) is positively correlated with capital expenditure. Also, Sofia and Syamsurizal (2010) confirmed that revenue sharing funds is correlated partially and simultaneously - with capital expenditure.

Hypothesis testing on the ratio of general allocation fund (DAU) to capital expenditure (CE) had a $0,0000<\alpha$ probability value $(0,05)$ with $-0,4004$ coefficient; therefore, DAU ratio had a significant but negative effect on capital expenditure. This hypothesis testing shows that the local government (district/city) was still dependent on financial aid from the central government to fulfil local expenditure. However, transfer funds in form of DAU is mostly allocated for operational expenses such as staff expenditure and goods and service compared to capital expenditure. Accordingly, the fifth hypothesis that DAU negatively affects capital expenditure is accepted. This finding supports Pramesti et al. (2015) that DAU did not affect capital expenditure allocation. Similarly, Wandira, (2013) and Nurhidayati and Yaya (2013) reported that DAU had a negative but significant effect on capital expenditure allocation.

The last hypothesis testing on special allocation fund ratio (DAK) to capital expenditure has a $0,0000<\alpha$ probability value $(0,05)$ with 0,1897 coefficient regression. Therefore, DAK had a positive and significant effect on capital expenditure. Accordingly, the sixth hypothesis that DAK positively affected capital expenditure is accepted. It shows that the local government (district/city) upholds the main objective of DAK allocation - an equitable development across regions that focus on special programs under the local government affairs. DAK is fully allocated for tangible and intangible capital expenditure to improve public facility. This finding supports Situngkir and Manurung (2009), Nuarisa (2013) and Nurhidayati and Yaya (2013) that DAK significantly affected capital expenditure.

\section{Conclusion}

The objective of this research was to investigate the effect of independent variables KKD, EFKT, LFE, DBH, DAU, and DAK on the dependent variable Capital Expenditure in thelocal government (district/city) in Indonesia. The results of hypothesis tests of all independent variables showed that not all variables affected capital expenditure. The results of hypothesis tests were as follows: 1) Local financial autonomy (KKD) had a negative but significant effect on Capital expenditure. 2) Local financial effectiveness (EFKT) had a positive and significant effect on Capital expenditure. 3) Local financial Efficiency (LFE) did not significantly affect Capital expenditure. 4) Revenue sharing funds (DBH) had a positive and significant effect on Capital expenditure. 5) General allocation fund (DAU) had a 
negative but significant Capital expenditure. 6) Special allocation fund (DAK) had a positive and significant Capital expenditure.

\section{Limitation and Reccommendation}

a. Independent variables of local government's financial performance ratio in this study is limited to Budget Realisation Report (LRA). Future studies may include financial performance ratio such as harmony, growth, the rate of decentralized fiscal, expenditure management, index of regular ability and others included in $23,13 \%$ proportion.

b. This research was only based on secondary quantitative data excluding the qualitative data. Therefore, future studies may address interview approach to gain more insights on the local policies to manage local financial resources allocated for capital expenditure.

c. Future studies may factor geographical condition, e.g. the difference across provinces to elaborate the specific needs for allocating capital expenditure. This information would be useful for the local government to establish a proper budget policy related to the infrastructure for public service or economy that may be different from one province to another.

d. Other variables that potentially determine capital expenditure should be factored such as SiLPA, the regional area and the characteristics of the local government.

\section{References}

Ardhini, \& Handayani, S. (2011). Pengaruh Rasio Keuangan Daerah Terhadap Belanja Modal untuk Pelayanan Publik Dalam Perspektif Teori Keagenan (Studi Pada Kabupaten dan Kota di Jawa Tengah).

Aryawati, N. P. A., \& Sudana, I. P. (2018). Kinerja Keuangan Memediasi Dana Perimbangan, Alokasi Belanja Daerah Pada Indeks Pembangunan Manuasia dan Pertumbuhan Ekonomi. Jurnal Ilmiah Akuntansi dan Bisnis, 13(1), 28-41. https://doi.org/10.24843/JIAB.2018.v13.i01.p04

Cho, I. G. (2018). Fiscal decentralization in Korea. Asian Education and Development Studies, 7(3), 279-290. https://doi.org/10.1108/AEDS-11-2017-0113

Faguet, J. P. (2004). Does Decentralization Increase Government Responsiveness to Local Needs? Evidence From Bolivia. Journal of Public Economics, 88(3-4), 867-893. https://doi.org/10.1016/S0047-2727(02)00185-8

Halim, A. (2004). Akuntansi Keuangan Daerah: Akuntansi Sektor Publik. Jakarta: Salemba Empat.

Halim, A. (2007). Akuntansi Keuangan Daerah: Akuntansi Sektor Publik. Edisi ke 3. Jakarta: Salemba Empat.

Halim, A. (2012). Akuntansi Keuangan Daerah: Akuntansi Sektor Publik. Edisi ke 4. Jakarta: Salemba Empat. 
Handayani, D., \& Nuraina, E. (2012). Pengaruh Pajak Daerah dan Dana Alokasi Khusus terhadap Alokasi Belanja Daerah Kabupaten Madiun. ASSETS: Jurnal Akuntansi dan Pendidikan, 1(1), 1-12. https://doi.org/10.25273/jap.v1i1.541

Haris, S. (2007). Desentralisasi dan Otonomi Daerah: Desentralisasi, Demokratisasi \& Akuntabilitas Pemerintah Daerah. Jakarta: LIPI Press.

Haryanto, J. T., \& Astuti, E. S. (2009). Desentralisasi Fiskal dan Penciptaan Stabilitas Keuangan Daerah. Kajian Ekonomi dan Keuangan, 13(1), 49-62.

Lembaran Negara Republik Indonesia. Undang-Undang Nomor 33 Tahun 2004 tentang Perimbangan Keuangan Antara Pemerintah Pusat dan Pemerintah Daerah.

Undang-Undang Nomor 32 Tahun 2004 tentang Pemerintahan Daerah.

Undang-Undang Nomor 9 Tahun 2015 tentang Perubahan Kedua atas Undang-Undang Nomor 23 Tahun 2014 tentang Pemerintahan Daerah.

Mahmudi. (2010). Analisis Laporan Keuangan Pemerintah Daerah, Edisi ke 2. Yogyakarta: Sekolah Tinggi Ilmu Manajemen YKPN.

Mardiasmo. (2004). Akuntansi Sektor Publik. Edisi II. Yogyakarta: ANDI.

Mardiasmo. (2009). Akuntansi Sektor Publik. Edisi IV. Yogyakarta: ANDI.

Martini, K., \& Dwirandra, A. A. N. B. (2015). Pengaruh Kinerja Keuangan Daerah pada Alokasi Belanja Modal di Provinsi Bali. E-Jurnal Akuntansi Universitas Udayana, 10(2), 426-443.

Muryawan, S. M., \& Sukarsa, M. (2016). Pengaruh Desentralisasi Fiskal, Fiscal Stress, dan Kinerja Keuangan Daerah Terhadap Pertumbuhan Ekonomi di Kabupaten/Kota Provinsi Bali. E-Jurnal Ekonomi dan Bisnis Universitas Udayana, 5(2), 229-252.

Nuarisa, S. A. (2013). Pengaruh PAD, DAU dan DAK Terhadap Pengalokasian Anggaran Belanja Modal. Accounting Analysis Journal, 2(1), 89-95.

Nugroho, I., \& Rokhmin D. 2012. Pembangunan Wilayah: Perspektif Ekonomi, Sosial dan Lingkungan. Jakarta: LP3ES.

Nurhidayati, L. L., \& Yaya, R. (2013). Alokasi Belanja Modal Untuk Pelayanan Publik: Praktik di Pemerintah Daerah. JAAI, 17(2), 102-114. https://doi.org/10.20885/jaai.vol17.iss2.art2

Nuryaman, \& Veronika, C. (2015). Metodologi Penelitian Akuntansi dan Bisnis: Teori dan Praktik. Bogor: Ghalia Indonesia.

Peraturan Pemerintah Republik Indonesia Nomor 71 Tahun 2010 tentang Standar Akuntansi Pemerintahan.

Nomor 58 Tahun 2005 tentang Pengelolaan Keuangan Daerah.

Peraturan Presiden Republik Indonesia Nomor 2 Tahun 2015 tentang Rencana Pembangunan 
Jangka Menengah Nasional (RPJMN) 2015-2019.

Pradiatmi, I. N. (2015). Pengaruh Kinerja Keuangan dan Belanja Modal Terhadap Pertumbuhan Ekonomi Pada Kabupaten/Kota Di Jawa Tengah. Jurnal Reviu Akuntansi dan Keuangan, 5(2), 759-768.

Pramesti, T., Taufik, T., \& Ratnawati, V. (2015). Pengaruh Pertumbuhan Ekonomi, Pendapatan Asli Daerah (PAD), Dana Alokasi Umum (DAU) dan Dana Alokasi Khusus (DAK) Terhadap Anggaran Belanja Modal Pemerintah Daerah Kabupaten/Kota di Indonesia. Jurnal Ekonomi, 23(4).

Purbadharmaja, I. B. P., Maryunani, Ananda, C. F., \& Santoso, D. B. (2018). The implications of fiscal decentralization and budget governance on economic capacity and community welfare. https://doi.org/10.1108/FS-05-2018-0052

Saragih, J. P. (2003). Desentralisasi Fiskal dan Keuangan Daerah dalam Otonomi. Jakarta: Gahlia Indonesia.

Situngkir, A. (2009). Pengaruh Pertumbuhan Ekonomi, Pendapatan Asli Daerah, Dana Alokasi Umum dan Dana Alokasi Khusus Terhadap Anggaran Belanja Modal Pada Pemko/Pemkab Sumatera Utara. Tesis, Universitas Sumatera Utara.

Situngkir, A., \& Manurung, J. S. (2009). Efek Memiliki Pendapatan Daerah, Pengalokasian Dana Umum, dan Dana Khusus Pada Belanja Modal di Kota dan Kabupaten Sumatera Utara. Kajian Akuntansi, 4(2), 93-103.

Sofia, A., \& Syamsurizal, I. (2010). Hubungan Pendapatan Asli Daerah, Dana Alokasi Umum, dan Dana Bagi Hasil Dengan Anggaran Belanja Modal pada Kabupaten dan Kotamadya di Jawa Barat. Jurnal Aset (Akuntansi Riset), 2(2), 369-378. https://doi.org/10.17509/jaset.v2i2.8916

Solikin, A. (2016). Analisis Flypaper Effect pada Pengujian Pengaruh Dana Alokasi Umum (DAU), Pendapatan Asli Daerah (PAD), dan Sisa Lebih Penghitungan Anggaran (SILPA) terhadap Belanja Pemerintah Daerah di Indonesia (Studi Tahun 2012-2014). Jurnal Akuntansi dan Bisnis, 16(1), 11-25. https://doi.org/10.20961/jab.v16i1.187

Subowo, \& Wati, E. R. (2010). Hubungan Antara PAD dan Dana Perimbangan dengan Belanja Modal Pemda Kudus. Jurnal Dinamika Akuntansi, 2(2), 73-82.

Suprayitno, B. (2015). Pengaruh Pertumbuhan Ekonomi , Pendapatan Asli Daerah dan Dana Alokasi Umum terhadap Anggaran Belanja Modal Pemerintah Provinsi di Pulau Jawa. Jurnal Riset Akuntansi dan Perpajakan JRAP, 2(1), 106-112.

Suwanda, S., \& Santosa, H. (2014). Kebijakan Akuntansi Berbasis Akrual Berpedoman Pada $S A P$. Bandung: PT Remaja Rosdakarya.

Tuasikal, A. (2008). Pengaruh DAU, DAK, PAD, dan PDRB Terhadap Belanja Modal Pemerintah Daerah Kabupaten/Kota di Indonesia. Jurnal Telaah \& Riset Akuntansi, 1(2), 142-154. https://doi.org/10.1016/j.ins.2004.04.013 


\section{Macrothink}

Journal of Public Administration and Governance ISSN 2161-7104 2019, Vol. 9, No. 4

Verawaty, Jaya, A. K., \& Megawati. (2016). Determinan Timeliness Penetapan APBD Pemerintah. Jurnal Akuntansi Multiparadigma (JAMAL). https://doi.org/10.18202/jamal.2016.12.7035

Wandira, A. G. (2013). Pengaruh PAD, DAU, DAK, dan DBH Terhadap Pengalokasian Belanja Modal. Accounting Analysis Journal, 2(33), 44-51. https://doi.org/ISSN 2252-6765

Waris, I. (2012). Pergeseran Paradigma Sentralisasi ke Desentralisasi Dalam Mewujudkan Good Governance. Jurnal Kebijakan Publik, 3(1), 1-55.

\section{Copyright Disclaimer}

Copyright for this article is retained by the author(s), with first publication rights granted to the journal.

This is an open-access article distributed under the terms and conditions of the Creative Commons Attribution license (http://creativecommons.org/licenses/by/4.0/). 